\title{
Biocontrol Effects of Paecilomyces variotii against Fungal Plant Diseases
}

\author{
Alejandro Moreno-Gavíra, Fernando Diánez (D), Brenda Sánchez-Montesinos and Mila Santos *D \\ Departamento de Agronomía, Escuela Superior de Ingeniería, Universidad de Almería, 04120 Almería, Spain; \\ alejanmoga@gmail.com (A.M.-G.); fdianez@ual.es (F.D.); brensam@hotmail.com (B.S.-M.) \\ * Correspondence: msantos@ual.es; Tel.: +34-950-015511
}

Citation: Moreno-Gavíra, A.; Diánez, F.; Sánchez-Montesinos, B.; Santos, M. Biocontrol Effects of Paecilomyces variotii against Fungal Plant Diseases. J. Fungi 2021, 7, 415. https://doi.org/ 10.3390/jof7060415

Academic Editors: Antonieta De Cal, Inmaculada Larena and

Paloma Melgarejo

Received: 30 April 2021

Accepted: 23 May 2021

Published: 26 May 2021

Publisher's Note: MDPI stays neutral with regard to jurisdictional claims in published maps and institutional affiliations.

Copyright: (c) 2021 by the authors. Licensee MDPI, Basel, Switzerland. This article is an open access article distributed under the terms and conditions of the Creative Commons Attribution (CC BY) license (https:// creativecommons.org/licenses/by/ $4.0 /)$.
Abstract: The genus Paecilomyces is known for its potential application in the control of pests and diseases; however, its use in agriculture is limited to few species. Research interest in new formulations based on microorganisms for the control of pathogens is growing exponentially; therefore, it is necessary to study new isolates, which may help control diseases effectively, and to examine their compatibility with established agricultural control methods. We analysed in vitro and in vivo the antagonistic capacity of Paecilomyces variotii against seven phytopathogens with a high incidence in different crops, and we examined its compatibility with 24 commercial fungicides. P. variotii was applied in the following pathosystems: B. cinereal-melon, Sclerotinia sclerotiorum-pepper, R. solanitomato, F. solani-zucchini, P. aphanidermatum-melon, M. melonis-melon, and P. xanthii-zucchini. The results showed strong control effects on M. melonis and P. xanthii, reducing the disease severity index by $78 \%$ and $76 \%$, respectively. The reduction in disease severity in the other pathosystems ranged from $29 \%$ to $44 \%$. However, application of metabolites alone did not cause any significant effect on mycelial growth of phytopathogens, apart from $F$. solani, in which up to $12 \%$ inhibition was observed in vitro when the extract was applied at a concentration of $15 \%$ in the medium. $P$. variotii was compatible with most of the tested fungicides, and of the 24 fungicides tested at the maximum authorised dose, 6 acted as fungicides, 4 as fungistatics, and the remaining showed inhibition rates ranging from $18.2 \%$ to $95.8 \%$. These results indicate that $P$. variotii is a potential biological control agent to be used against several aerial and soil diseases, thus it should be integrated into modern pest management strategies.

Keywords: Paecilomyces; biological control; endophyte; phytopathogens; aerial and soil diseases

\section{Introduction}

Various pests and diseases cause significant annual losses in global agriculture by reducing yield and crop quality [1,2] and such losses are estimated at around 20-40\%, which represents a significant economic impact valued at hundreds of millions of dollars per year $[3,4]$. Common practice for controlling such pathogens is the indiscriminate application of agrochemicals; however, biological control by endophytic microorganisms is a more environmentally friendly alternative [5-7].

The endophytic fungus Paecilomyces variotii is an ascomycete that is morphologically characterised by the development of verticillate conidiophores with irregular branches in which cylindrical phialides are inserted with a pronounced narrowing at the neck where yellow or pale brown conidia are located [8,9]. This fungus produces chlamydospores with walls that are smooth or slightly rough, depending on the strain. P. variotii is thermophilic, ubiquitous, and highly versatile, and its spores can withstand temperatures above $80{ }^{\circ} \mathrm{C}$ for 15 min [10]; furthermore, it grows rapidly, can develop under oxygen-limited conditions, and produces a wide range of metabolites, therefore this species stands out among decomposing fungi [11]. It can adapt to a large variety of habitats (in air, edaphic, and aquatic environments) and can be found in plant debris and compost, inside plants as an 
endophyte, and in animals as an opportunistic parasite, thereby contaminating human food and animal feed; furthermore, it occurs in municipal solid waste, in sediments and marine plants, and even within homes and operating rooms [12-18].

The potential of $P$. variotii and of its bioactive metabolites for controlling fungal diseases has been extensively studied [19]. This species can reduce mycelial development of numerous phytopathogens under in vitro culture conditions. In particular, P. variotii can inhibit the fungi Aspergillus niger [20], Botrytis cinerea [21], Fusarium graminearum [22], F. moniliforme [23], F. oxysporum [24-26], F. solani [27], Macrophomina phaseolina [27,28], Magnaporthe oryzae [29], Pyricularia oryzae [30], Pythium aphanidermatum [31,32], P. spinosum [33], Saccharomyces cerevisiae [30], Sclerotium rolfsii [27,33], and Verticillium dahilae [25], and the bacteria Bacillus cereus [34], B. subtilis [20], Escherichia coli, Micrococcus luteus [22,35], Pseudomonas aeruginosa [30,34], Staphylococcus aureus [22-35], Streptococcus iniae [35], Vibrio parahaemolyticus [22,34], and Xanthomonas campestris [24], among others.

Similarly, the in vivo biocontrol effects on certain pathogens by $P$. variotii has been described in field experiments in which it significantly reduced the incidence and severity of diseases in different crops. Such treatments resulted in significant improvements of germination proportion, length and weight of roots and aerial plant parts, and yield [26]. Taken together, $P$. variotii exhibits a positive effect when inoculated together with Alternaria alternata [36], Fusarium spp. [37], F. oxysporum [24,26], M. phaseolina [28,37], P. syringae [38], Rhizoctonia solani [37], P. aphanidermatum [32], X. campestris [24], and X. oryzae [38].

The use of endophytic microorganisms has the advantage of being safe for humans; however, they may occasionally elicit various adverse effects such as phytotoxicity or environmental dependence for adequate biological activity [23], which is why the use of bioactive extracts and metabolites of these endophytes, including P. variotii, is of considerable interest [39]. A multitude of compounds synthesised by this fungus and able to act as microbial control agents has been described, such as 6-decyl salicylic acid [40], phenopicolinic acid [25], eicosenoic acid [41], ascofuranone [42], betulin [34], sphingofungin E and F [43,44], lawsozaheer [45], paecilaminol [20], paecilocin A-D [40], paeciloxazine [44,46], peptaibols [47], chitinases [39], varioxepine A and B [22,48], viriditin A and B [49], viriditoxin, semi-viriditoxin, and semi-viriditoxic acid $[16,23,50]$.

The $P$. variotii isolate CDG33 has recently been characterised as a plant growth promoter [51]. The aims of the current study were (1) to determine in vitro antagonistic effects of P. variotii CDG33 and extracts thereof on different agriculturally important phytopathogens; (2) to examine its in vivo capacity for controlling the development of diseases caused by such phytopathogens in different pathosystems under greenhouse conditions; and (3) to assess the compatibility of $P$. variotii with different fungicides commonly used for fungal disease control.

\section{Materials and Methods}

\subsection{Fungal Isolates}

P. variotii CDG33 was obtained from autochthonous plants grown at the Cabo de Gata Natural Park, Almería, Spain [51]. This isolate has been tested to determine its potential biocontrol effect against Botrytis cinerea Pers, Sclerotinia sclerotiorum (Lib.) de Bary, Fusarium solani (Mart.) Sacc, Pythium aphanidermatum (Edson) Fitzp, Rhizoctonia solani J.G. Kühn, Mycosphaerella melonis (Pass.) and Podosphaera xanthii (Castagne) U. Braun \& Shishkoff.

Different crop plants infected with pathogens were collected in the province of Almería, Spain, during 2017-2019. Selected stem and leaf sections with active lesions were cut, and tissue sections from the boundaries between healthy and discoloured areas were placed in potato dextrose agar (PDA; Bioxon, Becton Dickinson, Mexico). Pathogenicity tests were carried out to confirm pathogenic capacity. 
The fungal isolate was grown and maintened on PDA in the dark at $25-27 \pm 2{ }^{\circ} \mathrm{C}$ for 5 or 10 days. Spore suspensions of P. variotii and phytopathogen isolates (except for R. solani, S. sclerotiorum, and P. xanthii) were prepared by flooding plates of 10-day-old cultures with sterile distilled water, scraping the surface using a sterile glass rod, and subsequent filtering of the suspensions, after which they were adjusted to a concentration of $1 \times 10^{6}$ spores $/ \mathrm{mL}$ using a Neubauer haemocytometer. In the case of $R$. solani and S. sclerotiorum, inoculation was performed using mycelium adjusted to a concentration of approximately $10^{4}$ colony forming units $/ \mathrm{mL}\left(\mathrm{CFU} \cdot \mathrm{mL}^{-1}\right)$. To produce mycelium, two agar plugs were cut from a colony and were placed in a flask containing PDB. The flasks were placed on a shaker for four days at $25^{\circ} \mathrm{C}$, and the content was homogenised for subsequent inoculation. The inoculum of $P$. xanthii was directly collected from affected leaves.

\subsection{Dual Culture Bioassays}

P. variotii was screened for in vitro antagonism against six phytopathogens using the confrontation assay of Santos et al. [52]. Petri dishes (9 $\mathrm{cm}$ diameter) containing $17 \mathrm{~mL}$ PDA were prepared, and $0.5 \mathrm{~cm}$ plugs of mycelium of all fungi were cut from the growing edge of 7-days-old cultures with active growth of each isolate. The plugs were placed at the margin of Petri dishes with a distance of $8 \mathrm{~cm}$ between the antagonist and phytopathogen fungi. A plug of PDA medium was used as a control treatment while the pathogen plug was placed at the other side. All plates were sealed using parafilm and were incubated in the dark at $25^{\circ} \mathrm{C}$ for different periods of time, depending on the growth rate of the respective pathogen (3-10 days).

Radial fungal colony growth was measured daily. Results were transformed into percentages of mycelium growth inhibition (PIRM). These tests were carried out using five replicates. The areas where antagonist and pathogen merged were also observed using a dissection microscope and a compound light microscope at 100-fold and 400-fold magnification.

\subsection{Effects of Non-Volatile Metabolites of P. variotii on Fungal Pathogens}

To determine the effects of non-volatile metabolites of P. variotii, $300 \mathrm{~mL}$ PDB medium was inoculated with two $0.5 \mathrm{~cm}$ plugs of mycelium and incubated without shaking at $25^{\circ} \mathrm{C}$ in the dark for $7,14,21,28,58,88$, and 118 days. Subsequently, the medium was filtered through double layered muslin cloth to remove mycelium and was sterilized by microfiltration through sterilized membranes of $0.22 \mu \mathrm{m}$ pore size (Merck Millipore, Burlington, MA, USA). Extracts were then incorporated and mixed with cooled PDA at 5, 10, and 15\% $(v / v)$ and were immediately poured into Petri dishes $(50 \mathrm{~mm})$. In the control treatments, distilled water was used instead of extract. Agar plugs $(0.5 \mathrm{~cm}$ diameter) covered with actively growing mycelia of the different pathogens were individually inoculated on the media and were incubated in the dark at $25^{\circ} \mathrm{C}$ for 10 days, apart from $P$. aphanidermatum which were incubated for 3 days, and S. sclerotiorum and B. cinerea which were incubated for 5 days under the same conditions. After incubation, mycelial growth of each fungus was measured as the average of two perpendicular diameters of the colony, and inhibitor effects were calculated in comparison to the controls. Five replicates were used for each incubation time and pathogen.

\subsection{Antifungal Volatile Organic Compounds Bioassay}

In vitro inhibition effects of volatile organic compounds produced by $P$. variotii against different phytopathogenic fungi was determined. For this, a plug $(0.5 \mathrm{~cm}$ diameter) was cut from the actively growing edges of $P$. variotii plates and was placed at the centre of $5.5 \mathrm{~cm}$ Petri dishes containing PDA medium. After two days of incubation of the antagonist, the same procedure was repeated for each of the pathogens, and a Cartesian axis was drawn from the centre of each plate to facilitate measurements. Both open plates were placed on the base of a square $12 \mathrm{~cm}$ Petri dish on which a further inverted base was placed after which they were sealed using parafilm. The air volume was approximately 
$403.20 \mathrm{~cm}^{3}$, preventing direct contact between the two fungi. The control plates were prepared following the same procedure but without the antagonist plug. The plates were incubated at $25 \pm 1{ }^{\circ} \mathrm{C}$, and mycelial growth of the pathogen was measured in both directions, which was performed daily for fungi with rapid growth (B. cinerea, S. sclerotiorum, P. aphanidermatum and R. solani) and every two days for those growing more slowly (M. melonis and F. solani), until the edge of the plate was reached. Three replicates were examined each day.

\subsection{Detached Leaf Assay}

Before the in vivo assay, suppressive effects of $P$. variotii on B. cinerea, S. sclerotiorum, and M. melonis were assessed using a detached leaf assay as described by Novak et al. [53] and Patial et al. [54]. Leaves of cucumber (variety Marketmore), pepper (var. red cherry) and tomato (var. Largo de Reus) seedlings were disinfected using 3\% sodium hypochlorite for $30 \mathrm{~s}$ and were washed twice to remove residues. The leaves were immersed for $3 \mathrm{~min}$ in a solution containing $P$. variotii spores at a dose of $10^{6}$ spores $\cdot \mathrm{mL}^{-1}$ or were immersed in an aqueous solution containing the fungicide Switch (cyprodinil $37.5 \%$ and fludioxonil $25 \%$ (WG) $w / w$; Syngenta, Basel, Switzerland) at $600 \mathrm{ppm}$, to compare efficacy. Whole leaves or fragments were then placed on wet filter paper in Petri dishes, and the centre of the leaf or leaf fragment was carefully punctured using a sterilised needle. A $0.5 \mathrm{~cm}$ plug containing the corresponding pathogen was placed at the puncture site. Petri dishes were then incubated at $25^{\circ} \mathrm{C}$, and number of leaves with symptoms were counted and photographed $72 \mathrm{~h}$ after inoculation. This experiment was repeated twice.

\subsection{Compatibility of P. variotii with Fungicides}

In vitro compatibility of $P$. variotii with different selected fungicides for mycelial growth inhibition was established using the poisoned food technique $[55,56]$. The minimum recommended dose (D2), the maximum recommended dose (D3), $0.5 \times \mathrm{D} 2$, and $1.5 \times \mathrm{D} 3$ (Table 1) of each fungicide were tested. Using a sterile cork borer, mycelial plugs $(0.5 \mathrm{~cm}$ diameter) were cut from actively growing seven-day-old fungal cultures and were placed in the centre of a Petri dish containing PDA supplemented with various pesticides. Five replicates were used per treatment. Fungicidal or fungistatic effects of each fungicide was determined by transferring the initial plug of $P$. variotii which did not grow with fungicide, to a PDA plate without fungicide.

Toxicity, i.e., compatibility of $P$. variotii and the fungicide, was classified using the scale of the International Organisation for Biological Control (OILB) [57]. This classification groups the compatibility between microorganisms and fungicides, depending on the proportion of inhibition compared to a control ( $<30 \%$ : harmless; $30-75 \%$ : slightly toxic; 75-90\%: moderately toxic; $>90 \%$ : toxic). 


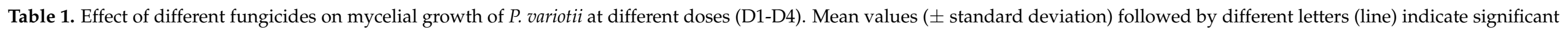

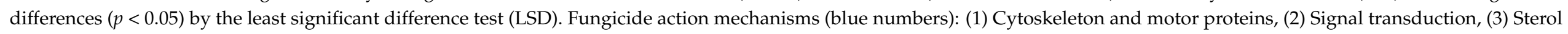

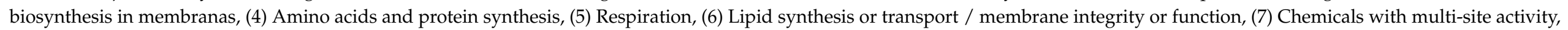

(8) Host plant defence induction, (9) Unknown mode of action, (10) Nucleic acids metabolism, and (11) Cell wall biosynthesis.

\begin{tabular}{|c|c|c|c|c|c|c|c|c|c|c|}
\hline \multirow[b]{3}{*}{$\begin{array}{l}\text { FUNGICIDE-ACTION } \\
\text { MECHANISMS }\end{array}$} & \multirow[b]{3}{*}{ D2 } & \multirow[b]{3}{*}{ D3 } & \multicolumn{8}{|c|}{ Doses (ppm) } \\
\hline & & & \multicolumn{2}{|c|}{ D1 $(0.5 \times$ D2 $)$} & \multicolumn{2}{|c|}{ D2 } & \multicolumn{2}{|c|}{ D3 } & \multicolumn{2}{|c|}{ D4 $(1.5 \times$ D3 $)$} \\
\hline & & & Growth & Inhib. & Growth & Inhib. & Growth & Inhib. & Growth & Inhib. \\
\hline Thiophanate-methyl 70\% (WP) w/w- (1) & 500 & 1000 & $27.8 \pm 2.8 \mathrm{a}$ & $60.1 \%$ & $13.6 \pm 1.7 \mathrm{~b}$ & $80.5 \%$ & $11.8 \pm 1.9 \mathrm{~b}$ & $83.0 \%$ & $12.6 \pm 1.5 \mathrm{~b}$ & $81.9 \%$ \\
\hline Diethofencarb 25\% (WP) w/w- (1) & 1000 & 1500 & $42.4 \pm 2.3 \mathrm{a}$ & $41.4 \%$ & $44.6 \pm 1.3 \mathrm{a}$ & $38.4 \%$ & $32.8 \pm 2.9 \mathrm{~b}$ & $54.7 \%$ & $18.2 \pm 1.3 c$ & $74.9 \%$ \\
\hline Pencycuron $25 \%$ (SC) w/v- (1) & 5000 & 8000 & $58.2 \pm 5.8 \mathrm{a}$ & $19.6 \%$ & $60.8 \pm 4.8$ a & $16.0 \%$ & $59.2 \pm 3.3 \mathrm{a}$ & $18.2 \%$ & $63.2 \pm 1.6 \mathrm{a}$ & $12.7 \%$ \\
\hline Iprodione $50 \%$ (SC) $w / v-(2)$ & 1000 & 1500 & $0 \pm 0 \mathrm{a}$ & $100.0 \%$ & $0 \pm 0 \mathrm{a}$ & $100.0 \%$ & $0 \pm 0 \mathrm{a}$ & $100.0 \%$ & $0 \pm 0 \mathrm{a}$ & $100.0 \%$ \\
\hline Triadimenol $25 \%$ (EC) $w / v-(3)$ & 250 & 500 & $61 \pm 8.6 \mathrm{a}$ & $1.0 \%$ & $36.8 \pm 6 \mathrm{~b}$ & $40.3 \%$ & $26.8 \pm 3 c$ & $56.5 \%$ & $29 \pm 1.9 c$ & $52.9 \%$ \\
\hline Myclobutanil 24\% (EC) w/v- (3) & 200 & 400 & $17.6 \pm 2.4 \mathrm{a}$ & $71.4 \%$ & $16 \pm 1 \mathrm{a}$ & $74.0 \%$ & $15.4 \pm 1.1 \mathrm{a}, \mathrm{b}$ & $75.0 \%$ & $13.2 \pm 1.6 \mathrm{~b}$ & $78.6 \%$ \\
\hline Tetraconazole $12.5 \%$ (ME) w/v- (3) & 200 & 400 & $21 \pm 1.6 \mathrm{a}$ & $68.7 \%$ & $4.4 \pm 1.3 \mathrm{~b}$ & $93.4 \%$ & $0 \pm 0 \mathrm{c}$ & $100.0 \%$ & $0 \pm 0 \mathrm{c}$ & $100.0 \%$ \\
\hline Fenhexamid 50\% (WG) $w / w-(3)$ & 1500 & 2000 & $14 \pm 2.1 \mathrm{a}$ & $77.3 \%$ & $9.2 \pm 0.4 \mathrm{a}$ & $85.1 \%$ & $3 \pm 0.7 \mathrm{~b}$ & $95.1 \%$ & $3.7 \pm 0.7 \mathrm{c}$ & $94.0 \%$ \\
\hline Pyrimethanil 40\% (SC) P/V- (4) & 1500 & 2000 & $0 \pm 0 \mathrm{a}$ & $100.0 \%$ & $0 \pm 0 \mathrm{a}$ & $100.0 \%$ & $0 \pm 0 \mathrm{a}$ & $100.0 \%$ & $0 \pm 0 \mathrm{a}$ & $100.0 \%$ \\
\hline Azoxystrobin 25\% (SC) w/v- (5) & 800 & 1000 & $22.2 \pm 3.2 \mathrm{a}$ & $64.0 \%$ & $18 \pm 2.2 \mathrm{a}$ & $70.8 \%$ & $19.4 \pm 1.5 \mathrm{a}$ & $68.5 \%$ & $19.2 \pm 2.8 \mathrm{a}$ & $68.8 \%$ \\
\hline Kresoxim-methyl 50\% (WG) w/w- (5) & 200 & 500 & $31 \pm 1.6 \mathrm{a}$ & $53.7 \%$ & $31.4 \pm 0.5 \mathrm{a}$ & $53.1 \%$ & $26.8 \pm 4.9 \mathrm{~b}$ & $60.0 \%$ & $28 \pm 2.1 \mathrm{a}, \mathrm{b}$ & $58.2 \%$ \\
\hline Etridiazole $48 \%$ (EC) $w / v-(6)$ & 2000 & 3000 & $5.6 \pm 0.9 \mathrm{a}$ & $92.3 \%$ & $1.6 \pm 0.5 \mathrm{~b}$ & $97.8 \%$ & $0 \pm 0 \mathrm{c}$ & $100.0 \%$ & $0 \pm 0 \mathrm{c}$ & $100.0 \%$ \\
\hline Propamocarb $60.5 \%$ (SL) w/v- (6) & 2500 & 5000 & $56.4 \pm 4.9 \mathrm{a}$ & $22.1 \%$ & $62.8 \pm 6.6 \mathrm{a}$ & $13.3 \%$ & $59.2 \pm 3.3 \mathrm{a}$ & $18.2 \%$ & $64.4 \pm 2.5 \mathrm{a}$ & $11.0 \%$ \\
\hline Mancozeb $80 \%$ (WG) w/w- (7) & 2000 & 3000 & $6 \pm 1.2 \mathrm{a}$ & $90.3 \%$ & $4 \pm 0.7 \mathrm{~b}$ & $93.5 \%$ & $2.6 \pm 0.9 c$ & $95.8 \%$ & $2.2 \pm 0.4 \mathrm{c}$ & $96.4 \%$ \\
\hline Chlorothalonil 50\% (SC) w/v- (7) & 2500 & 3000 & $13.6 \pm 1.8 \mathrm{a}$ & $77.9 \%$ & $13.4 \pm 1.8 \mathrm{a}$ & $78.2 \%$ & $15.2 \pm 1.8 \mathrm{a}$ & $75.3 \%$ & $15.4 \pm 1.5 \mathrm{a}$ & $75.0 \%$ \\
\hline Fosetyl-AL 80\% (WG) w/w- (8) & 2500 & 3000 & $52.4 \pm 1.8 \mathrm{a}$ & $14.9 \%$ & $41.8 \pm 1.3 \mathrm{~b}$ & $32.1 \%$ & $39.2 \pm 2.5 c$ & $36.4 \%$ & $35.4 \pm 1.8 \mathrm{~d}$ & $42.5 \%$ \\
\hline Cymoxanil 60\% (WG) w/w- (9) & 200 & 300 & $36.2 \pm 4 \mathrm{a}$ & $46.0 \%$ & $16.2 \pm 0.8 \mathrm{~b}, \mathrm{c}$ & $75.8 \%$ & $17 \pm 1.6 \mathrm{~b}$ & $74.6 \%$ & $13.2 \pm 1.6 \mathrm{c}$ & $80.3 \%$ \\
\hline $\begin{array}{l}\text { Cyprodinil } 37.5 \% \text { + Fludioxonil } 25 \% \\
\text { (WG) } w / w-(4+2)\end{array}$ & 600 & 1000 & $0 \pm 0 \mathrm{a}$ & $100.0 \%$ & $0 \pm 0 \mathrm{a}$ & $100.0 \%$ & $0 \pm 0 \mathrm{a}$ & $100.0 \%$ & $0 \pm 0 \mathrm{a}$ & $100.0 \%$ \\
\hline $\begin{array}{l}\text { Folpet } 40 \%+\text { Metalaxyl-M 10\% (WP) } \\
w / w-(7+10)\end{array}$ & 2000 & 2500 & $0 \pm 0 \mathrm{a}$ & $100.0 \%$ & $0 \pm 0 \mathrm{a}$ & $100.0 \%$ & $0 \pm 0 \mathrm{a}$ & $100.0 \%$ & $0 \pm 0 \mathrm{a}$ & $100.0 \%$ \\
\hline $\begin{array}{l}\text { Dimethomorph } 7.5 \%+\text { Mancozeb } 66.7 \% \\
\text { (WG) } w / w-(11+7)\end{array}$ & 2000 & 3000 & $0 \pm 0 \mathrm{a}$ & $100.0 \%$ & $0 \pm 0 \mathrm{a}$ & $100.0 \%$ & $0 \pm 0 \mathrm{a}$ & $100.0 \%$ & $0 \pm 0 \mathrm{a}$ & $100.0 \%$ \\
\hline $\begin{array}{l}\text { Benalaxil 6\% + Cymoxanil 3.2\% + } \\
\text { Mancozeb } 40 \%(\mathrm{WP}) w / w-(10+9+7)\end{array}$ & 2500 & 3500 & $0 \pm 0 \mathrm{a}$ & $100.0 \%$ & $0 \pm 0 \mathrm{a}$ & $100.0 \%$ & $0 \pm 0 \mathrm{a}$ & $100.0 \%$ & $0 \pm 0 \mathrm{a}$ & $100.0 \%$ \\
\hline
\end{tabular}




\subsection{Greenhouse Evaluation of P. variotii on Disease Severity of Seven Phytopathogens}

Biocontrol effects of $P$. variotii on different pathosystems was determined: B. cinerealmelon (var. Piel de Sapo), S. sclerotiorum - pepper (var. Red Cherry), R. solani-tomato (var. Largo de Reus), F. solani-zucchini (P. aphanidermatum-melon, M. melonis-melon, and P. xanthii-zucchini (var. Milenio). Seeds were disinfected using $2 \%$ hypochlorite for $3 \mathrm{~min}$ and were washed thoroughly with tap water to eliminate residues. Subsequently, the seeds were sown in $500 \mathrm{~mL}$ pots containing a commercial peat mix at one seed per pot. A $5 \mathrm{~mL}$ spore suspension of each isolate of $P$. variotii (PAE) was added to each pot at $1 \times 10^{6}$ propagules/plant; the control treatments received $5 \mathrm{~mL}$ water. To assess diseases of aerial parts, foliar spraying was carried out at the same dose to wet the whole plant with the $P$. variotii solution. Spraying was carried out three days before applying conidia/mycelium of the respective pathogen.

To prepare P. aphanidermatum inocula the procedure described by Marin et al. [58] was followed. Inocula of the other phytopathogens were prepared by scraping and subsequent filtration as previously described, apart from R. solani, S. sclerotiorum and P. xanthii. Phytopathogens were inoculated when the plants showed a second true leaf, and using a sterile micropipette, inoculation was performed by uniformly applying the zoospores/conidia suspension $\left(5 \mathrm{~mL}\right.$ ) at a concentration of $10^{4} \mathrm{CFU} \cdot \mathrm{mL}^{-1}$ uniformly to the peat surface. In the case of $B$. cinerea and M. melonis, the pathogen was applied by spraying the plant five times at the same concentration $(6 \mathrm{~mL})$. Before this, the first true leaf had been cut to facilitate pathogen entry. Inoculation with $R$. solani was carried out by mixing mycelium into the substrate; inoculation with $S$. sclerotiorum was performed using the spray mycelium method as described by Chen and Wang [59]. The stem was wounded to facilitate pathogen entry. Symptom severity was recorded continuously, and 30-60 days after inoculation, a final disease severity index was estimated according to the following scale: $0=$ healthy plant; $1=$ initial symptoms; $2=$ moderate symptoms $(25 \%) ; 3=$ affected plant $(50 \%) ; 4=$ severely affected plant $(75 \%)$; and $5=$ dead plant (Figure 1 ).
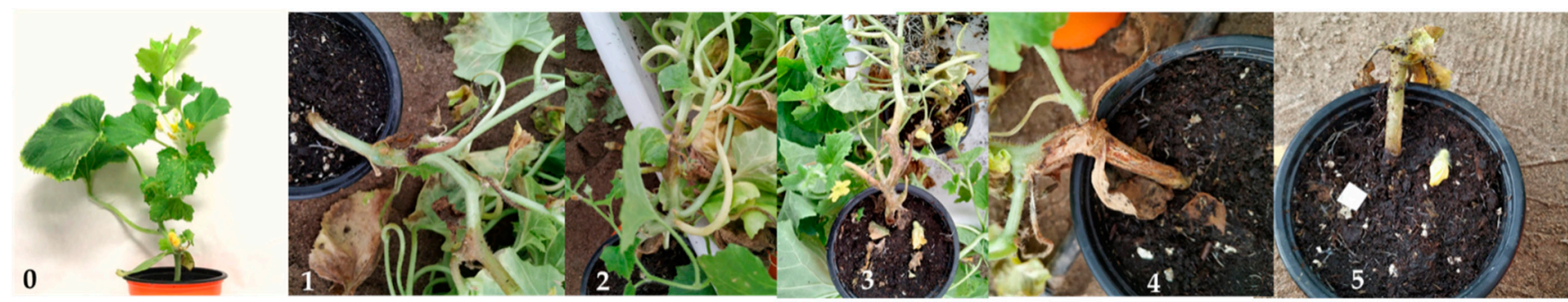

Figure 1. Example of the disease severity scale for M. melonis. $\mathbf{0}=$ healthy plant; $\mathbf{1}=$ initial symptoms; $\mathbf{2}=$ moderate symptoms (25\%); 3 = affected plant (50\%); 4 = severely affected plant $(75 \%) ; \mathbf{5}=$ dead plant.

To determine the control effect of $P$. variotii on powdery mildew, an inoculum of P. xanthii was prepared from field-collected zucchini leaves affected by cucurbit powdery mildew (Figure 2). Using a sprayer, sterile distilled water was sprayed under pressure to rinse the leaves of fungal conidia. The suspension was collected, and experimental plants were immediately inoculated at a concentration of $10^{4} \mathrm{CFU} \cdot \mathrm{mL}^{-1}$. To determine the suppressive effect of $P$. variotii on the disease, the leaf area (Figure 2) affected by powdery mildew was determined using WinDIAS 3.1.lnk software (Dynamax, Fresno, CA, USA) to calculate the proportion of affected leaf area with respect to total leaf area. Additionally, the numbers of affected leaves and petioles per plant were counted. 


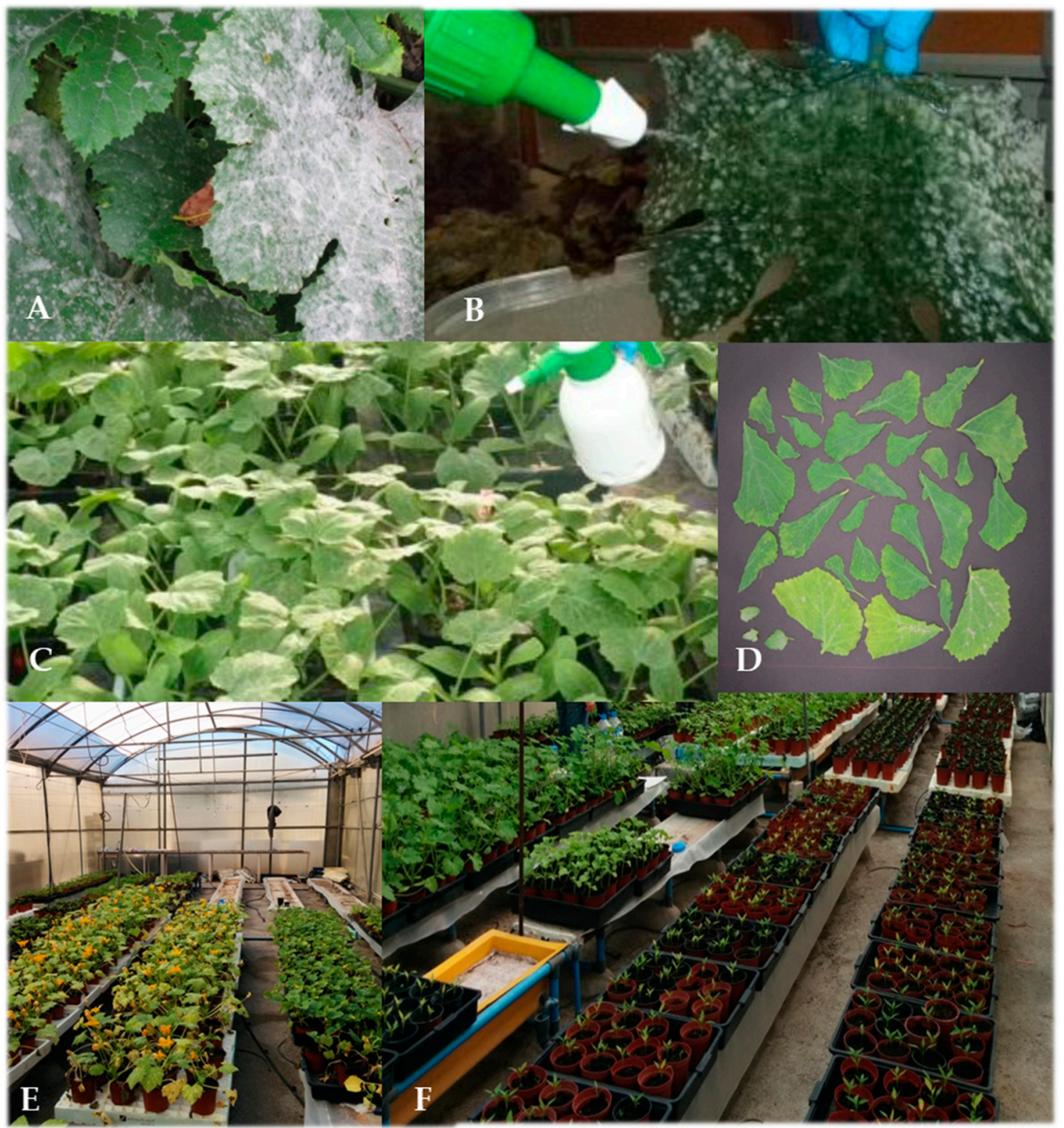

Figure 2. (A). Zucchini leaves with symptoms of powdery mildew caused by P. xanthii. (B). Application of sterile water for rinsing off spores. (C). Spraying of spores on healthy seedlings previously treated with P. variotii (PAE) or water (T0). (D). Arrangement of leaves to determine the affected leaf area. (E,F). Distribution of seedlings during the different assays.

All pathogenicity tests were performed under greenhouse conditions and in different seasons to provide optimal environmental conditions for each pathogen. Experimental units consisted of four repetitions with 24 plants per pathosystem. Two experiments were conducted using a completely randomized block design.

\subsection{Statistical Analyses}

Data were analysed using analysis of variance with Statgraphics Centurion version XVI software. A preliminary test was performed to assess the normal distribution of the data. Mean separation was carried out using Fisher's least significant difference test. Data were tested using a one-way analysis of variance or Student's $t$-test; statistical significance is reported at $p<0.05$. 


\section{Results}

\subsection{In Vitro Antagonism of P. variotii}

The results of the dual culture assay, expressed as inhibition percentages, are shown in Figure 3. Colony growth of P. variotii occurred rapidly ( $48-72 \mathrm{~h}$ ) with isolated colonies covering the plate, demonstrating the inhibitory effect of the antagonist (Figure 4). The highest percentages of inhibition were detected in P. aphanidermatum and F. solani. Moreover, P. variotii initially showed inhibition of approximately $2 \mathrm{~mm}$ (Figure 4), which subsequently disappeared under direct contact between the two colonies. This inhibition zone indicates the presence of fungistatic metabolites secreted by P. variotii. Parasitism was not observed, even though hyphal destruction and vacuole formation were observed.

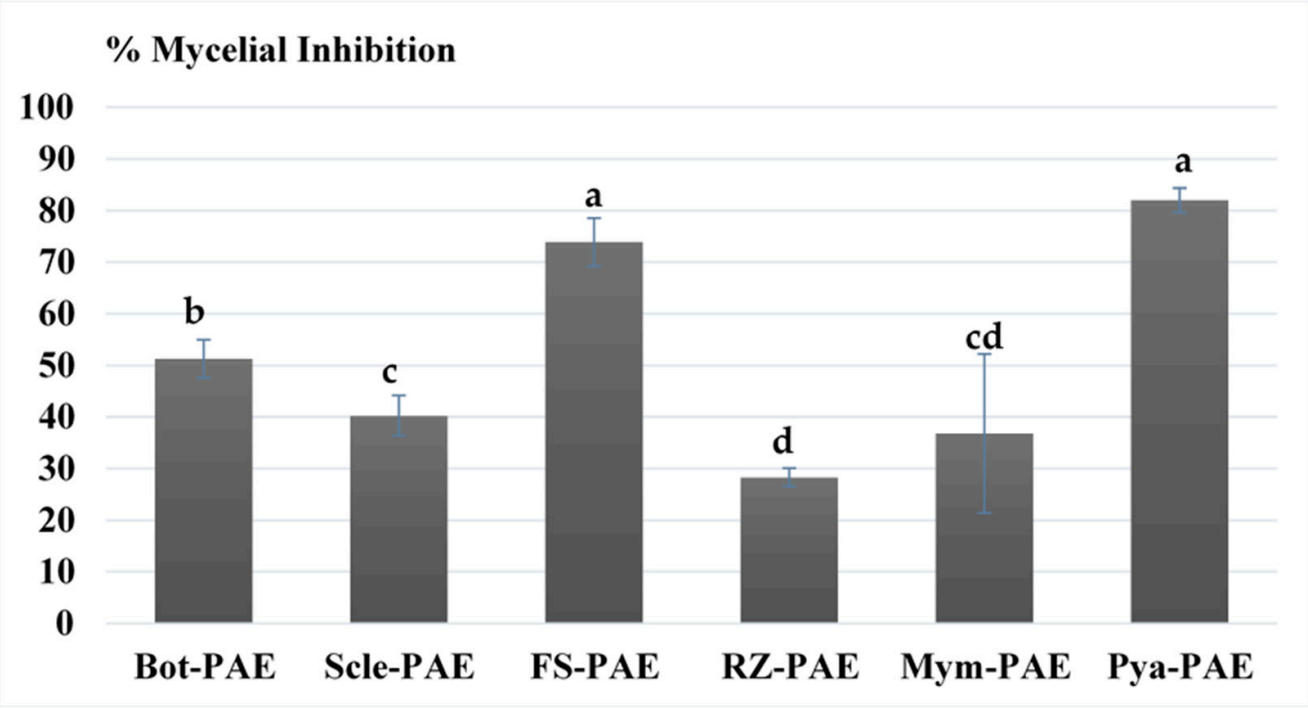

Figure 3. Antagonistic effects of Paecilomyces variotii (PAE) on Botrytis cinerea (Bot), Sclerotinia sclerotiorum (Scle), Fusarium solani (FS), Pythium aphanidermatum (Pya), Rhizoctonia solani (Rz), and Mycosphaerella melonis (Mym) in dual culture on PDA medium. Percent mycelial inhibition was calculated as PIRM $=((R 1-R 2) / R 1) \times 100$, where PIRM is the percentage of inhibition of radial mycelia growth of the pathogen. $\mathrm{R} 1$ is radial growth of the pathogen in control plates, and $\mathrm{R} 2$ is radial growth of the pathogen in dual cultures. Means with the same letter are not significantly different (least significant difference test) according to an analysis of variance $(p>0.05)$.

3.2. In Vitro Effects of Cell-Free Filtrate and Antifungal Volatile Compounds of P. variotii on Mycelial Growth of Phytopathogens

Cell-free filtrate of $P$. variotii did not show any inhibitory effect on mycelial growth of the analysed fungi in the different tested conditions, except for F. solani, which showed inhibition ranging from $1.7 \%$ to $12 \%$ at concentrations of $10 \%$ and $15 \%$, regardless of the incubation time (Figure 5). 


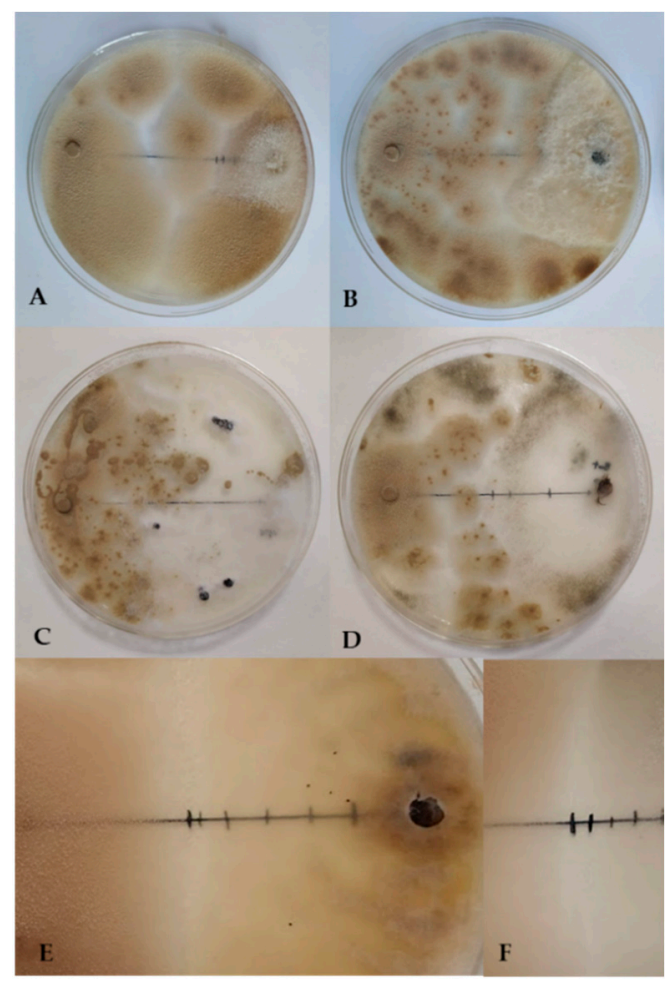

Figure 4. In vitro antagonistic effects of P. variotii on F. solani (A), M. melonis (B), S. sclerotiorum (C), and B. cinerea (D) in $9 \mathrm{~cm}$ Petri dishes. Inhibition zone between $P$. variotii and the phytopathogens $M$. melonis (E) and F. solani (F) (Images 75\% increased).

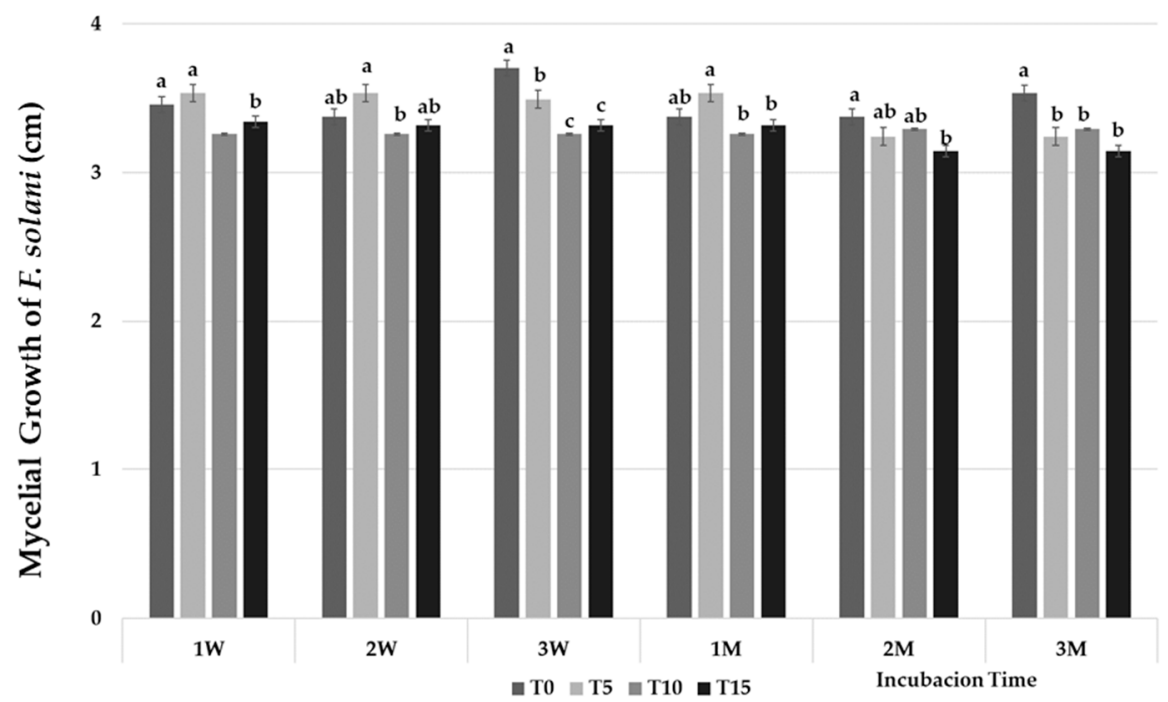

Figure 5. Effect of the cell-free filtrate of $P$. variotii culture on mycelial growth of $F$. solani. Incubation time: 1, 2, and 3 weeks (W); 1, 2, and 3 months (M). T0, T5, T10, T15: \% extracts incorporated and mixed with cooled PDA at 0 (Control), 5, 10, and 15\% (v/v). Means with the same letter are not significantly different (least significant difference test) according to an analysis of variance.

By contrast, volatile metabolites of $P$. variotii showed no significant inhibition of the tested fungi. In the case of M. melonis, low inhibition of $5 \%$ and $7 \%$ were observed for the $\mathrm{L} 1$ and $\mathrm{L} 2$ readings (L), respectively. For F. solani, 3.2\% inhibition was detected in the L3 reading (Figure 6). 


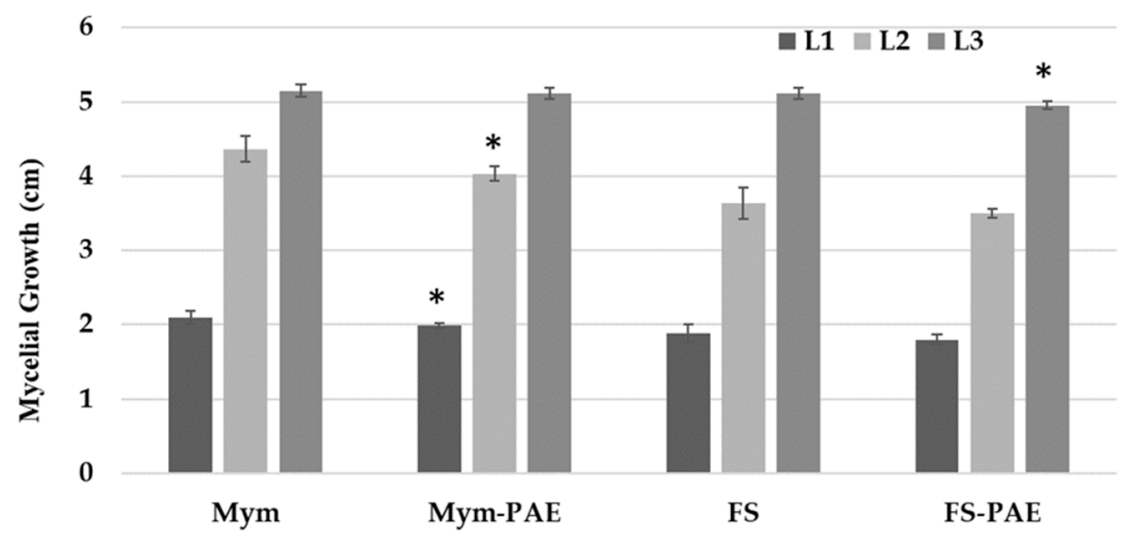

Figure 6. Effect of volatile metabolites of P. variotii on mycelial growth of M. melonis and F. solani. L1, L2, and L3: measurements performed every two days. Data were analysed using Student's t-test. Means with * denote significant difference between both treatments according a pairwise comparison using Student's t-test $(p<0.05)$.

\subsection{Compatibility for Use of P. variotii with Fungicides}

The observed effects of 24 fungicides on growth and development of $P$. variotii are presented in Table 1 . The results indicate that mycelial growth of $P$. variotii was affected by the different doses of each of the fungicides tested in vitro, compared to the control. According to the OILB scale [57], the compatibility of the 24 fungicides tested for minimum (D2) and maximum (D3) recommended doses in horticultural crops was as follows: 2 were harmless (Pencycuron and Propamocarb; inhibition $<30 \%$ ), 6 were slightly toxic (diethofencarb, triadimenol, myclobutanil, azoxystrobin, kresoxim-methyl, and Fosetyl-AL; 30-75\%), 4 were moderately toxic (thiophanate-methyl, flutriafol, Chlorothalonil, and Cymoxanil; $75-90 \%$ ), and 10 were toxic (iprodione, tetraconazole, pyrimethanil, etridiazole, copper oxychloride, mancozeb, cyprodinil + fludioxonil, Folpet + metalaxyl-M, dimethomorph + mancozeb, and benalaxil + cymoxanil + mancozeb; >90\%). Only two fungicides (fenhexamid and copper hydroxide) showed different behaviour according to the scale at maximum and minimum doses; both were toxic at the maximum doses (D3) and slightly toxic and moderately toxic, respectively, at the minimum doses (D2). The four fungicides formulated with two or three active ingredients were toxic, with $100 \%$ mycelial growth inhibition at all tested doses; one mixture (cyprodinil + fludioxonil) was fungistatic, and the other three were fungicidal. Of the remaining six toxic fungicides, total growth inhibition was observed only in three and five at doses D2 and D3, respectively, with fungicidal effects only using pyrimethanil at the minimum dose (D2) and with iprodione, pyrimethanil, and etridiazole at the maximum dose (D3).

\subsection{Detached Leaves}

Inoculation of detached cucumber, pepper, and tomato leaves with mycelium of B. cinerea, S. sclerotiorum, and M. melonis resulted in marked inhibition of disease development in leaves inoculated with $P$. variotii, at the same efficacy as the control fungicide. Leaves not inoculated with $P$. variotii showed mycelial growth and obvious symptoms of rotting (Figure 7). 


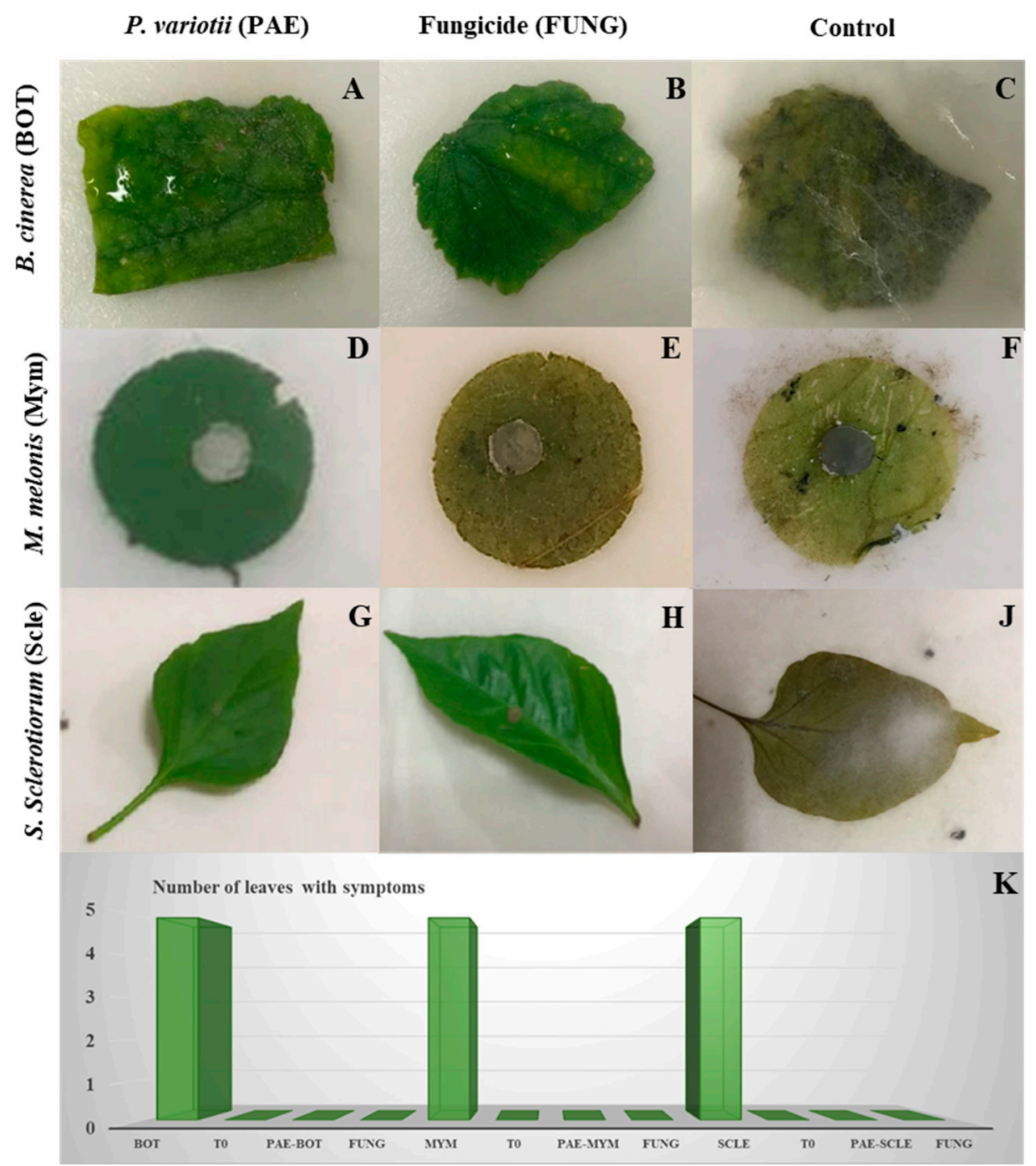

Figure 7. Visual symptoms of B. cinerea (A-C), M. melonis (D-F), and S. sclerotiorum $(\mathbf{G}, \mathbf{H}, \mathbf{J})$ infection on detached leaves treated with $P$. variotii $(\mathbf{A}, \mathbf{D}, \mathbf{G})$ or fungicide $(\mathbf{B}, \mathbf{E}, \mathbf{H})$. Control $(\mathbf{C}, \mathbf{F}, \mathbf{J})$ : visual symptoms without $P$. variotii or fungicide. (K). Number of leaves with symptoms in each treatment.

\subsection{In Vivo Suppressive Effects of P. variotii on Diseases Caused by Phytopathogenic Fungi}

In general, the severity of disease caused by different soil and aerial phytopathogens decreased due to application of $P$. variotii (Figure 8). The strongest biocontrol effect occurred against stem gummosis, with a reduction of $78 \%$ in disease severity after infection with by M. melonis after spraying with $P$. variotii. Lower values occurred in the other phytopathogen experiments. Reductions of $44 \%, 38.88 \%$, and $37.20 \%$ in disease severity after infection with B. cinerea, S. sclerotiorum, and R. solani, respectively, were observed. Due to the random arrangement of treatments, disease was also observed in the uninoculated controls (T0) of some of the pathosystems. The highest disease severity indices following application of $P$. variotii occurred in the P. aphanidermatum and F. solani treatments, as opposed to the in vitro results, with a reduction of $31.11 \%$ and $28.57 \%$, respectively. In the case of $F$. solani, all plants treated with $P$. variotii reached disease grade 5 , showing a delay of approximately 10 days.

Foliar application of P. variotii considerably suppressed the disease caused by P. xanthii (Figure 9), with a reduction of $75.80 \%$ in the proportion of leaf area showing symptoms. Similarly, the number of leaves and petioles with powdery mildew was reduced by $30.4 \%$ and $17.4 \%$, respectively. 


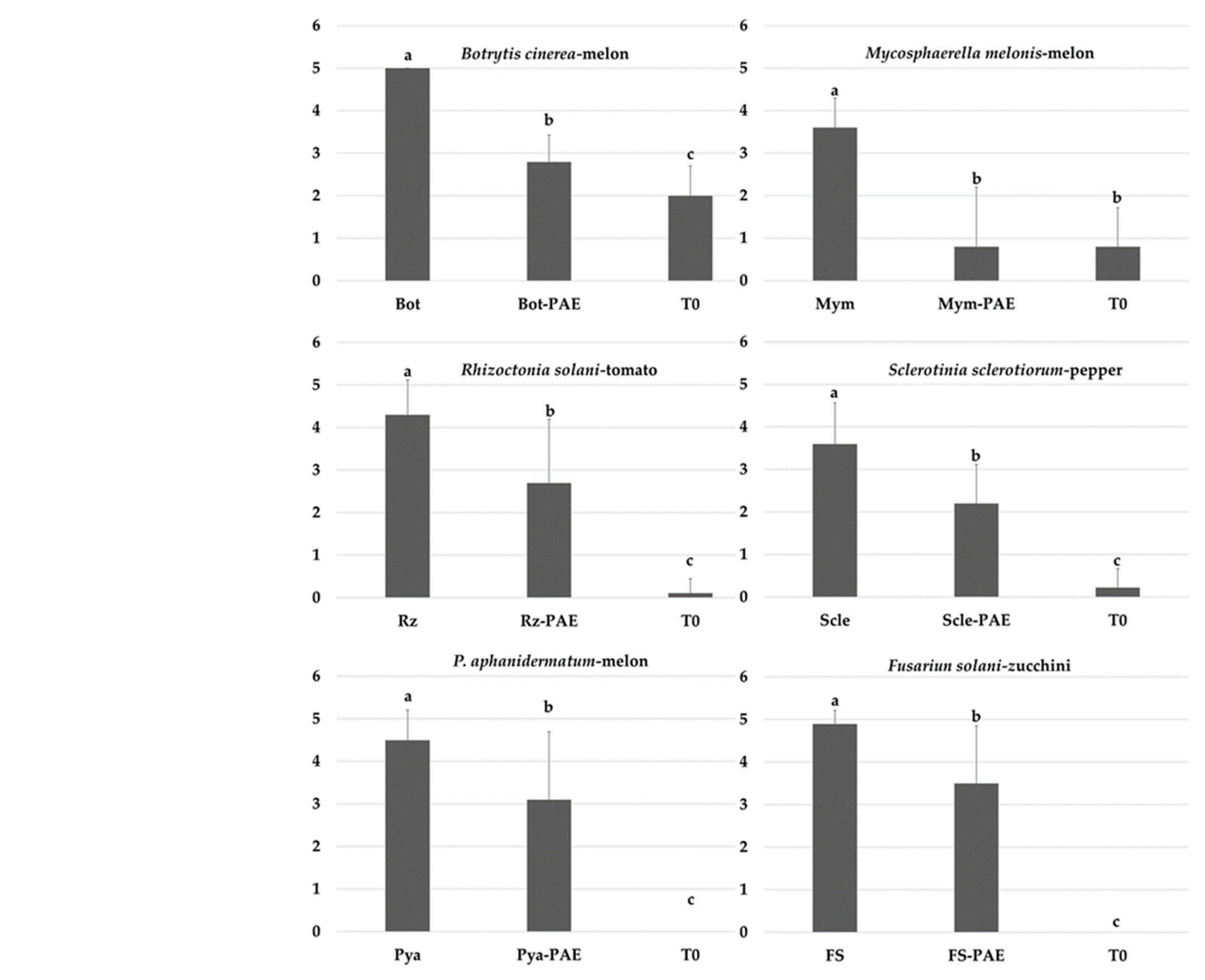

Figure 8. Disease severity of phytopathogens in plants was assessed 30-60 days after inoculation based on a scale from 0 to 5 , where 0 indicates no visible disease symptoms and 5 indicates a dead plant. Bars indicate mean standard deviations (24 plants/repetition). Means with the same letter are not significantly different (least significant differences) according to an analysis of variance.

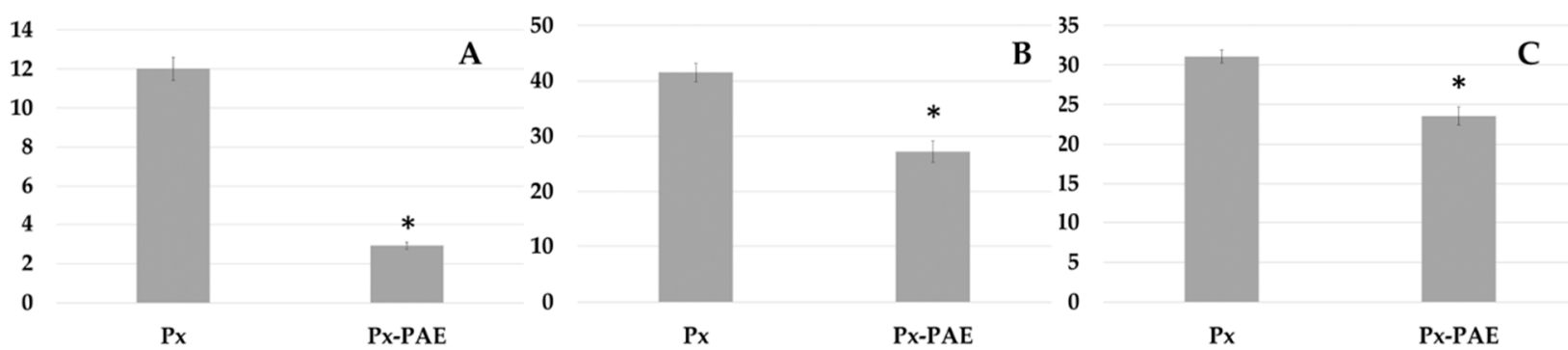

Leaf area with symptoms per plant (\%) No. leaves with symptoms per plant $(\%) \quad$ No. petioles with symptoms per plant $(\%)$

Figure 9. Control of $P$. xanthii by spraying zucchini plants with $P$. variotii. (A). Mean proportion of leaf area with powdery mildew symptoms per plant. (B). Percentage of the number of leaves with symptoms per plant. (C). Percentage of number of petioles with powdery mildew. Px: Application of P. xanthii. Px-PAE: Application of P. variotii three days before application of $P$. xanthii. Means with * denote significant difference between both treatments according a pairwise comparison using Student's t-test $(p<0.05)$. 


\section{Discussion}

P. variotii has been described as a biological control agent of fungal and bacterial diseases. Its biocontrol effect is mostly due to its rapid growth and sporulation, resulting in higher competition success for space and available resources compared to other species [60]. However, few studies have conducted in vivo experiments on disease control by $P$. variotii [19].

The current study analysed in vitro and in vivo suppressive effects of P. variotii CDG33 on several phytopathogenic fungi that cause diseases of aerial and soil parts of crop plants. In vitro antagonism results based on the dual culture technique showed very heterogeneous values in terms of inhibition percentages, ranging from $25 \%$ to $82.0 \%$. Results obtained in in vitro experiments can vary substantially depending on experimental conditions and may differ even between isolates of the same species. Perveen et al. [33] reported similar results from the dual culture of $P$. variotii and P. aphanidermatum, with an inhibition percentage of $67-72 \%$, whereas Rodrigo et al. [23] observed lower values that did not exceed $40 \%$. In the present study, inhibition of $P$. aphanidermatum exceeded $80 \%$, which is mainly due to the rapid dispersal of $P$. variotii spores during the experiment. Moreover, substantial inhibition of $F$. solani was observed, which is in line with the results of Ramzan et al. [27]. However, no direct relationship between in vitro and in vivo antagonism values was found, especially regarding P. aphanidermatum and F. solani. The same was observed in R. solani and M. melonis, which, despite showing the lowest in vitro antagonism values of no more than $40 \%$, showed the highest disease reduction values in the plant experiments. This has been commonly observed [61,62] and can be caused, among other factors, by differences in techniques and components, such as the culture medium, presence of soil or substrate, and the plant itself. Even so, it is one of the most commonly used techniques and is considered the basis for screening microorganisms as a preliminary step to in vivo experiments, and to produce effective biological control agents in agriculture.

P. variotii produces a large number of volatile and non-volatile compounds $[19,63,64]$; however, little or no inhibition effect of the metabolites produced by isolate CDG33 on the tested phytopathogens was observed. This may be because the effect of volatile and non-volatile metabolites on the tested phytopathogens decreases over time within the first 24-48 $\mathrm{h}$, and the diameter of the fungal colony in the treatments with filtrate was similar to that of the control. Only a mild inhibitory effect of non-volatile metabolites on F. solani was observed. Rodrigo et al. [23] obtained similar results, with a significant reduction of $F$. moniliforme with P. variotii filtrates. Such a time-dependent decrease in the effect of metabolites on Biscogniauxia mediterranea, the causal agent of charcoal disease in cork oak, was described previously [65].

It is important to assess compatibility of biological control agents and agrochemicals by using a combination of chemical and biological tools. Chemical treatments should be based on selection of agrochemicals with the lowest impact on biological control agents. Many studies, even though in clinical settings, confirmed the incompatibility of $P$. variotii with several fungicides, since different species of the genus Paecilomyces cause a variety of infections in immunocompromised patients [66-68]. Furthermore, previous studies indicate that Paecilomyces isolates from agricultural environments are more resistant to common fungicides. This is the case with $P$. niveus isolates from naturally occurring infections in apples, where it can cause post-harvest spoilage and patulin accumulation [69]. Species of the genus Paecilomyces may differ regarding their compatibility with fungicides, which may, however, also be the case regarding different strains of the same species due to genetic differences [70,71]. Even though the results obtained in the laboratory may not confirm those of the field experiments due to the higher severity of in vitro assays, our results indicate that $P$. variotii may be compatible with many of the tested fungicides regarding fungistatic effects or reduction of growth rates. Of the 24 tested fungicides, only 4 were incompatible at the minimum recommended doses, and 6 at the maximum doses. Particularly when fungicide mixtures with different modes of action are used, these products may thus interfere with successful biological control by P. variotii, 
which showed $100 \%$ fungal inhibition with fungicidal effects on $P$. variotii in three of the tested formulations. Regarding fungicides with one active ingredient, only iprodione, pyrimethanil, and etridiazole acted as fungicides in the authorised dose range. Other products that completely inhibited growth, such as tetraconazole, copper hydroxide, and copper oxychloride, were not biocidal.

Similar results were obtained by Er and Gökçe [72] who applied iprodione at 500 ppm active ingredient (ai) to an isolate of Paecilomyces fumosoroseus, even though a reduction of $51 \%$ in mycelial growth was observed using a different isolate, Loureiro et al. [73] classified the effect of iprodione on P. fumosoroseus as toxic at $500 \mathrm{ppm}$ ai and very toxic at $750 \mathrm{ppm}$ ai; Biango-Daniels et al. [69] analysed the compatibility of 30 isolates of $P$. niveus with the fungicide pyrimethanil to determine the effective fungicide dose at which growth was inhibited by $50 \%\left(E_{C} 50\right)$. The $E_{C} 50 \%$ values ranged from 29 to 109 and were higher in isolates from crops. In the current study, the lowest tested dose (D1; 100 ppm ai) completely inhibited growth, although without a fungicidal effect which only occurred using higher doses. In contrast, the study of Gallego-Velásquez et al. [74] showed that the application of ethidiazole at $350 \mathrm{ppm}$ ai completely inhibited growth of P. lilacinum. In our study, complete inhibition of $P$. variotii growth occurred at dose D3 (1440 ppm ai), and growth inhibition above $92 \%$ was observed only at 960 and 480 ppm ai. Other studies showed that copper hydroxide at 1660 and 2592 ppp ai used on P. fumosoroseus resulted in growth inhibition of approximately 9\% and 82\%, respectively [75], while Dermici and Denihan [76] observed a minimum inhibitory concentration of $>5000 \mathrm{ppm}$ ai for P. lilacinus. Copper oxychloride at $1500 \mathrm{ppm}$ ai completely inhibits growth of P. lilacinus [76], however others found inhibition of only $44.1 \%$ using copper oxychloride at $4200 \mathrm{ppm}$ ai. In the current study, copper oxychloride completely inhibited growth of $P$. variotii at all doses, and copper hydroxide did the same at the highest dose, thus both compounds were fungistatic. By contrast, Ondráčková et al. [76] observed growth inhibition of $79.6 \%$ in P. lilacinus treated with mancozeb at 1500 ppm ai; the lowest dose tested in our study was 800 ppm ai, which resulted in $>90 \%$ inhibition, and it was not fungicidal at any of the tested doses. The fungicides pencycuron and propamocarb were compatible with $P$. variotii at all tested doses. These results corroborate those of previous studies on the effects of pencycuron at 540 ppm ai [77] and propamocarb at 1042.5 ppm ai [74] on P. lilacinus.

The present study demonstrated a high capacity of $P$. variotii CDG33 to reduce the severity of diseases caused by different aerial and soil phytopathogens in vivo, even though some pathogens showed very limited inhibition in vitro, according to a previous study [78]. The genus Paecilomyces is best known for its role as an entomopathogen and nematophagus fungus; however, other research findings also support the use of Paecilomyces fungi to prevent or treat fungal diseases [79]. In this regard, P. variotii has been previously described as a BCA in in vivo experiments in which the application of this microbial antagonist reduced colonisation of sunflower seedlings with M. phaseolina [28]. Similarly, Maitlo et al. [26] showed a significant reduction in the severity of disease caused by F. oxysporum $\mathrm{f}$. sp. ciceris from $80 \%$ (control) to $6 \%$ and $36 \%$ following the application of $P$. variotii and P. lilacinus, respectively. By contrast, in vitro inhibition percentages of $P$. tenuis were described previously [80], which are similar to those observed in our study, particularly regarding $R$. solani $(28 \%)$ and F. oxysporum (51\%), even though lower concentrations of Pythium sp. (24\%) were used.

No inhibitory effect on phytopathogens through volatile metabolites was observed. A previous study showed in vitro inhibition of $B$. cinerea by approximately $43 \%$ due to $P$. variotii [21] which is lower than the inhibition effect exerted by the $P$. variotii isolate CDG33, and this study suggested a significant reduction in rotting of kiwifruit caused by Botrytis, which was more effective than the conventional fungicide vinclozolin. Similar in vitro antagonism values (44\%) of Paecilomyces sp. were observed in a study conducted by Marín-Chacón et al. [81]. 


\section{Conclusions}

According to our results, the application of the ascomycete P. variotii CDG33 as a preventive and/or control of fungal plant diseases may be a viable alternative to the use of conventional synthetic compounds. These insights can help reduce the amount of agrochemicals used which may leak into other ecosystems, and will therefore help reduce the environmental burden of agriculture.

Author Contributions: F.D. and M.S. conceived and designed the experiments; A.M.-G. and B.S.-M. performed the experiments; F.D. analyzed the data; M.S. wrote the paper. All authors have read and agreed to the published version of the manuscript.

Funding: The present work benefited from the input of the project RTC-2017-6486-2 and was supported by the Spanish Ministry of Science, Innovation and Universities.

Institutional Review Board Statement: Not applicable.

Informed Consent Statement: Not applicable.

Conflicts of Interest: The authors declare that there is no conflict of interests regarding the publication of this manuscript.

\section{References}

1. Romanazzi, G.; Smilanick, J.L.; Feliziani, E.; Droby, S. Integrated management of postharvest gray mold on fruit crops. Postharvest Biol. Technol. 2016, 113, 69-76. [CrossRef]

2. Romeralo, C.; Santamaría, O.; Pando, V.; Diez, J.J. Fungal endophytes reduce necrosis length produced by Gremmeniella abietina in Pinus halepensis seedlings. Biol. Control 2015, 80, 30-39. [CrossRef]

3. Xiong, W.; Li, R.; Ren, Y.; Liu, C.; Zhao, Q.; Wu, H.; Alexandre, J.; Qirong, S. Distinct roles for soil fungal and bacterial communities associated with the suppression of vanilla Fusarium wilt disease. Soil Biol. Biochem. 2017, 107, 198-207. [CrossRef]

4. Gastavsson, J.; Cederberg, C.; Sonesson, U. Global Food Losses and Food Waste; Food and Agriculture Organization (FAO) of the United Nations: Rome, Italy, 2011; p. 37.

5. Savary, S.; Ficke, A.; Aubertot, J.N.; Hollier, C. Crop losses due to diseases and their implications for global food production losses and food security. Food Secur. 2012, 4, 519-537. [CrossRef]

6. Sellem, I.; Triki, M.A.; Elleuch, L.; Cheffi, M.; Chakchouk, A.; Smaoui, S.; Mellouli, L. The use of newly isolated Streptomyces strain TN258 as potential biocontrol agent of potato tubers leak caused by Pythium ultimum. J. Basic Microbiol. 2017, 57, 393-401. [CrossRef] [PubMed]

7. Li, H.; Guan, Y.; Dong, Y.; Zhao, L.; Rong, S.; Chen, W.; Lv, M.; Xu, H.; Gao, X.; Chen, R.; et al. Isolation and evaluation of endophytic Bacillus tequilensis GYLH001 with potential application for biological control of Magnaporthe oryzae. PLoS ONE 2018, 13, e203505. [CrossRef] [PubMed]

8. Samson, R.A.; Houbraken, J.; Varga, J.; Frisvad, J.C. Polyphasic taxonomy of the heat resistant ascomycete genus Byssochlamys and its Paecilomyces anamorphs. Persoonia 2009, 22, 14. [CrossRef] [PubMed]

9. Nguyen, T.T.T.; Paul, N.C.; Lee, H.B. Characterization of Paecilomyces variotii and Talaromyces amestolkiae in Korea based on the morphological characteristics and multigene phylogenetic analyses. Mycobiology 2016, 44, 248-259. [CrossRef]

10. Houbraken, J.; Varga, J.; Rico-Munoz, E.; Johnson, S.; Samson, R.A. Sexual reproduction as the cause of heat resistance in the food spoilage fungus Byssochlamys spectabilis (anamorph Paecilomyces variotii). Appl. Environ. Microbiol. 2008, 74, 1613-1619. [CrossRef] [PubMed]

11. Houbraken, J.; Samson, R.A.; Frisvad, J.C. Byssochlamys: Significance of Heat Resistance and Mycotoxin Production. In Advances in Food Mycology; Springer: Boston, MA, USA, 2006; pp. 211-224.

12. Samson, R.A.; Houbraken, J.; Summerbell, R.C.; Flannigan, B.; Miller, J.D. Common and important species of fungi and actinomycetes in indoor environments. In Microorganisms in Home and Indoor Work Environments: Diversity, Health Impacts, Investigation and Control; Wiley: Boca Raton, FL, USA, 2002; pp. 285-473.

13. He, J.; Kang, J.; Lei, B.; Wen, T. Paecilomyces wawuensis, a new species isolated from soil in China. Mycotaxon 2011, 115, 303-310. [CrossRef]

14. Hussain, A.; Shrivastav, A.; Jain, S.K.; Baghel, R.K.; Rani, S.; Agrawal, M.K. Cellulolytic enzymatic activity of soft rot filamentous fungi Paecilomyces variotii. Adv. Biores. 2012, 3, 10-17.

15. Marante, F.J.T.; Mioso, R.; Barrera, J.B.; González, J.E.G.; Rodríguez, J.J.S.; De Laguna, I.H.B. Structural characterization and metabolite profiling of the facultative marine fungus Paecilomyces variotii. Ann. Microbiol. 2012, 62, 1601-1607. [CrossRef]

16. Silva, M.O.; Kawai, K.; Hosoe, T.; Takaki, G.C.; Gusmão, N.B.; Fukushima, K. Viriditoxin, An Antibacterial Substance Produced by Mangrove Endophytic Fungus Paecilomyces variotii. In Microbial Pathogens and Strategies for Combating Them: Science, Technology and Education; Formatex: Badajoz, Spain, 2013; Volume 2, pp. 1406-1411. 
17. Steiner, B.; Aquino, V.R.; Paz, A.A.; Silla, L.M.D.R.; Zavascki, A.; Goldani, L.Z. Paecilomyces variotii as an emergent pathogenic agent of pneumonia. Case Rep. Infect. Dis. 2013, 273848. [CrossRef]

18. Li, X.Q.; Xu, K.; Liu, X.M.; Zhang, P.A. Systematic review on secondary metabolites of Paecilomyces species: Chemical diversity and biological activity. Planta Med. 2020, 86, 805-821. [CrossRef]

19. Moreno-Gavíra, A.; Huertas, V.; Diánez, F.; Sánchez-Montesinos, B.; Santos, M. Paecilomyces and its importance in the biological control of agricultural pests and diseases. Plants 2020, 9, 1746. [CrossRef] [PubMed]

20. Ui, H.; Shiomi, K.; Suzuki, H.; Hatano, H.; Morimoto, H.; Yamaguchi, Y.; Masuma, R.; Sakamoto, K.; Kita, K.; Miyoshi, H.; et al. Paecilaminol, a new NADH-fumarate reductase inhibitor, produced by Paecilomyces sp. FKI-0550. J. Antibiot. 2006, 59, 591-596. [CrossRef]

21. Pratella, G.C.; Mari, M. Effectiveness of Trichoderma, Gliocladium and Paecilomyces in postharvest fruit protection. Postharvest Biol. Technol. 1993, 3, 49-56. [CrossRef]

22. Zhang, P.; Li, X.M.; Wang, J.N.; Wang, B.G. Oxepine-containing diketopiperazine alkaloids from the algal-derived endophytic fungus Paecilomyces variotii EN-291. Helv. Chim. Acta 2015, 98, 800-804. [CrossRef]

23. Rodrigo, S.; Santamaria, O.; Halecker, S.; Lledó, S.; Stadler, M. Antagonism between Byssochlamys spectabilis (anamorph Paecilomyces variotii) and plant pathogens: Involvement of the bioactive compounds produced by the endophyte. Ann. Appl. Biol. 2017, 171, 464-476. [CrossRef]

24. Suárez-Estrella, F.; Arcos-Nievas, M.A.; López, M.J.; Vargas-García, M.C.; Moreno, J. Biological control of plant pathogens by microorganisms isolated from agro-industrial composts. Biol. Control 2013, 67, 509-515. [CrossRef]

25. Arora, K.; Sharma, S.; Krishna, S.B.; Adam, J.K.; Kumar, A. Non-edible Oil cakes as a novel substrate for DPA production and augmenting biocontrol activity of Paecilomyces variotii. Front. Microbiol. 2017, 8, 753. [CrossRef] [PubMed]

26. Maitlo, S.A.; Rajput, N.A.; Syed, R.N.; Khanzada, M.A.; Rajput, A.Q.; Lodhi, A.M. Microbial control of Fusarium wilt of chickpea caused by Fusarium oxysporum f. sp. ciceris. Pak. J. Bot. 2019, 51, 2261-2268. [CrossRef]

27. Ramzan, N.; Shahzad, S. Inhibition of in vitro growth of soil-borne pathogens by compost-inhabiting indigenous bacteria and fungi. Pak. J. Bot. 2014, 46, 1093-1099.

28. Anis, M.; Abbasi, M.W.; Zaki, M.J. Bioefficacy of microbial antagonists against Macrophomina phaseolina on sunflower. Pak. J. Bot. 2010, 42, 2935-2940.

29. Khanzada, M.; Shah, G.S. In-Vitro evaluation of fungicides, plant extracts and bio-control agents against rice blast pathogen Magnaporthe oryzae couch. Pak. J. Bot. 2012, 44, 1775-1778.

30. Mohammadi, S.; Soltani, J.; Piri, K. Soilborne and invertebrate pathogenic Paecilomyces species show activity against pathogenic fungi and bacteria. J. Crop Prot. 2016, 5, 377-387. [CrossRef]

31. Al-Sheikh, H.; Abdelzaher, H.M.A. Isolation of Aspergillus sulphureus, Penicillium islandicum and Paecilomyces variotii from agricultural soil and their biological activity against Pythium spinosum, the damping-off organism of soybean. J. Biol. Sci. 2010, 10, 178-189. [CrossRef]

32. Amrina, H.; Shahzad, S.; Siddiqui, Z.S. Photochemistry of Luffa cylindrica (L.) Roem under fungal biocontrol interaction. Photosynthetica 2018, 56, 743-749. [CrossRef]

33. Perveen, Z.; Ramzan, N.; Noreen, N.; Rajpuit, A.Q.; Shahzad, S. In vitro evaluation of biocontrol potential of Paecilomyces species against Sclerotium rolfsii and Pythium aphanidermatum. Int. J. Biol. Biotechnol. 2015, 12, 407-411.

34. Barakat, K.; Saleh, M. Bioactive betulin produced by marine Paecilomyces WE3-F. J. Appl. Pharm. Sci. 2016, 6, 34-40. [CrossRef]

35. Liu, J.; Li, F.; Lee, Y.M.; Li, J.L.; Hong, J.K.; Yoon, W.D.; Kim, E.K.; Jung, J.H. An anacardic acid analog from the jellyfish-derived fungus Paecilomyces variotii. Nat. Prod. Sci. 2012, 18, 8-12.

36. Varma, P.K.; Gandhi, S.K.; Surender, S. Biological control of Alternaria solani, the causal agent of early blight of tomato. J. Biol. Control 2008, 22, 67-72.

37. Sarfaraz, H.; Tariq, M.; Dawar, S. Utilization of microbial antagonists with Thuja orientalis L. for the control of pathognic fungi. Int. J. Biol. Res. 2017, 5, 15-20.

38. Lu, C.; Liu, H.; Jiang, D.; Wang, L.; Jiang, Y.; Tang, S.; Hou, X.; Han, X.; Liu, Z.; Zhang, M. Paecilomyces variotii extracts (ZNC) enhance plant immunity and promote plant growth. Plant Soil 2019, 441, 383-397. [CrossRef]

39. Herrera, I.; Toledo, F.J.; Mioso, R. Enzymes and bioproducts produced by the ascomycete fungus Paecilomyces variotii. J. Appl. Microbiol. 2015, 119, 1455-1466. [CrossRef]

40. Liu, J.; Li, F.; Kim, E.L.; Li, J.L.; Hong, J.; Bae, K.S.; Chung, H.Y.; Hyung, S.K.; Jung, J.H. Antibacterial polyketides from the jellyfish-derived fungus Paecilomyces variotii. J. Nat. Prod. 2011, 74, 1826-1829. [CrossRef]

41. Horn, W.S.; Kurtz, M.B.; Liesch, J.M.; Smith, J.L.; Martin, I.; Vicente, F. Antibiotic Eicosenoic Acids and Their Manufacture with Paecilomyces variotii. U.S. Patent US523306, 1993.

42. Terekhova, L.P.; Trenin, A.S.; Ozerskaya, S.M.; Rudenskaya, Y.A.; Maksimova, T.S.; Katrukha, G.S.; Potapova, N.P.; Kosykh, V.A. B synthesis of ascofuranone by the fungus Paecilomyces variotii Bainier. Микробиология 1997, 66, 611-615.

43. Martinková, M.; Gonda, J.; Raschmanová, J.Š.; Slaninková, M.; Kuchár, J. Total synthesis of a protected form of sphingofungin E using the (3, 3)-sigmatropic rearrangement of an allylic thiocyanate as the key reaction. Carbohydr. Res. 2010, 345, $2427-2437$. [CrossRef] [PubMed] 
44. Degenkolb, T.; Vilcinskas, A. Metabolites from nematophagous fungi and nematicidal natural products from fungi as an alternative for biological control. Part I: Metabolites from nematophagous ascomycetes. Appl. Microbiol. Biotechnol. 2016, 100, 3799-3812. [CrossRef] [PubMed]

45. Abbas, Z.; Siddiqui, B.S.; Shahzad, S.; Sattar, S.; Begum, S.; Batool, A.; Choudhary, M.I. Lawsozaheer, a new chromone produced by an endophytic fungus Paecilomyces variotii isolated from Lawsonia Alba Lam. inhibits the growth of Staphylococcus aureus. Nat. Prod. Res. 2020, 1-6. [CrossRef]

46. Kanai, Y.; Fujimaki, T.; Kochi, S.I.; Konno, H.; Kanazawa, S.; Tokumasu, S. Paeciloxazine, a novel nematicidal antibiotic from Paecilomyces sp. J. Antibiot. 2004, 57, 24-28. [CrossRef]

47. Hegde, V.R.; Silver, J.; Patel, M.; Gullo, V.P.; Puar, M.S.; Das, P.R.; Loebenberg, D. Novel fungal metabolites as cell wall active antifungals. J. Antibiot. 2003, 56, 437-447. [CrossRef] [PubMed]

48. Zhang, P.; Li, X.M.; Mao, X.X.; Mándi, A.; Kurtán, T.; Wang, B.G. Varioloid A, a new indolyl-6, 10b-dihydro-5aH-[1] benzofuro [2, 3-b] indole derivative from the marine alga-derived endophytic fungus Paecilomyces variotii EN-291. Beilstein J. Org. Chem. 2016, 12, 2012-2018. [CrossRef] [PubMed]

49. López-Fernández, S.; Campisano, A.; Schulz, B.J.; Steinert, M.; Stadler, M.; Surup, F. Viriditins from Byssochlamys spectabilis, their stereochemistry and biosynthesis. Tetrahedron Lett. 2020, 61, 151446. [CrossRef]

50. Hyung, J.J.; Kang, H.; Joong, J.J.; Soo, K.Y. Paecilomyces Variotii Extracts for Preventing and Treating Infections Caused by Fish Pathogenic Microorganisms. KR Patent 2013051523, 2013.

51. Moreno-Gavíra, A.; Diánez, F.; Sánchez-Montesinos, B.; Santos, M. Paecilomyces variotii as a plant-growth promoter in horticulture. Agronomy 2020, 10, 597. [CrossRef]

52. Santos, M.; Dianez, F.; Gonzalez del Valle, M.; Tello, J.C. Grape marc compost: Microbial studies and suppression of soil-borne mycosis in vegetable seedlings. World J. Microbiol. Biotechnol. 2008, 24, 1493-1505. [CrossRef]

53. Novak, N.G.; Perez, F.G.; Jones, R.W.; Lawrence, S.D. Detached leaf assays to simplify gene expression studies in potato during infestation by chewing insect Manduca sexta. J. Vis. Exp. 2019, 147. [CrossRef]

54. Patial, M.; Kumar, J.; Pal, D. Detached leaf assay for evaluating resistance to leaf rust Pst. 104-2 in wheat (Triticum aestivum L.). Indian J. Exp. Biol. 2017, 55, 789-794.

55. Diánez, F.; Santos, M.; Blanco, R.; Tello, J.C. Fungicide resistance in Botrytis cinerea isolates from strawberry crops in huelva (Southwestern Spain). Phytoparasitica 2002, 30, 529-534. [CrossRef]

56. Nene, Y.L.; Thapliyal, R.N. Evaluation of Fungicides for Plant Disease Control, 3rd ed.; IBH Publishing Co.: New Dehli, India, 1993; p. 33.

57. Viñuela, E.; Jacas, J.A.; Marco, V.; Adan, A.; Budia, F. Los efectos de los plaguicidas sobre los organismos beneficiosos en agricultura. Grupo de trabajo de OILB plaguicidas y organismos beneficiosos. I. Insecticidas y acaricidas. Phytoma 1993, 45, 18-25.

58. Marín, F.; Diánez, F.; Santos, M.; Carretero, F.; Gea, F.J.; Castañeda, C.; Navarro, M.J.; Yau, J.A. Control of Phytophthora capsici and Phytophthora parasitica on pepper (Capsicum annuum L.) with compost teas from different sources, and their effects on plant growth promotion. Phytopathol. Mediterr. 2014, 53, 216-228.

59. Chen, Y.; Wang, D. Two convenient methods to evaluate soybean for resistance to Sclerotinia sclerotiorum. Plant Dis. 2005, 89, 1268-1272. [CrossRef] [PubMed]

60. Adebola, M.O.; Amadi, J.E. Antagonistic activities of Paecilomyces and Rhizopus species against the cocoa black pod pathogen (Phytophthora palmivora). Afr. Sci. 2010, 11, 235-239.

61. Comby, M.; Gacoin, M.; Robineau, M.; Rabenoelina, F.; Ptas, S.; Dupont, J.; Bailliieul, F. Screening of wheat endophytes as biological control agents against Fusarium head blight using two different in vitro tests. Microbiol. Res. 2017, 202, 11-20. [CrossRef] [PubMed]

62. Besset-Manzoni, Y.; Joly, P.; Brutel, A.; Gerin, F.; Soudière, O.; Langin, T.; Prigent-Combaret, C. Does in vitro selection of biocontrol agents guarantee success in planta? A study case of wheat protection against Fusarium seedling blight by soil bacteria. PLoS ONE 2019, 5, 2-18. [CrossRef] [PubMed]

63. Mioso, R.; Marante, F.J.T.; De Laguna, I.H.B. The chemical diversity of the ascomycete fungus Paecilomyces variotii. Appl. Biochem. Biotechnol. 2015, 177, 781-791. [CrossRef]

64. Dai, Z.B.; Wang, X.; Li, G.H. Secondary Metabolites and their bioactivities produced by Paecilomyces. Molecules 2020, $25,5077$. [CrossRef] [PubMed]

65. Aronson, J.; Pereira, J.S.; Pausas, J.G. Cork Oak Woodlands on the Edge. Ecology, Adaptative Management and Restoration; Island Press: Washington, DC, USA, 2009.

66. Houbraken, J.; Verweij, P.E.; Rijs, A.J.M.M.; Borman, A.M.; Samson, R.A. Identification of Paecilomyces variotii in clinical samples and settings. J. Clin. Microbiol. 2010, 48, 2754-2761. [CrossRef]

67. Chamilos, G.; Kontoyiannis, D.P. Voriconazole-resistant disseminated Paecilomyces variotii infection in a neutropenic patient with leukaemia on voriconazole prophylaxis. Clin. Case Rep. 2005, 51, 225-228. [CrossRef]

68. Aguilar, C.; Pujol, I.; Sala, J.; Guarro, J. Antifungal susceptibilities of Paecilomyces species. Antimicrob. Agents Chemother. 1998, 42, 1601-1604. [CrossRef]

69. Biango-Daniels, M.N.; Ayer, K.M.; Cox, K.D.; Hodge, K.T. Paecilomyces niveus: Pathogenicity in the orchard and sensitivity to three fungicides. Plant Dis. 2019, 103, 125-131. [CrossRef]

70. Cantone, F.A.; Vandenberg, J.D. Intraspecific diversity in Paecilomyces fumosoroseus. Mycol. Res. 1998, 102, 209-215. [CrossRef] 
71. Tigano-Milani, M.S.; Honeycutt, R.J.; Lacey, L.A.; Assis, R.; McClelland, M.; Sobral, B.W.S. Genetic variability of Paecilomyces fumosoroseus isolates revealed by molecular markers. J. Invertebr. Pathol. 1995, 65, 274-282. [CrossRef]

72. Er, M.K.; Gökçe, A. Effects of selected pesticides used against glasshouse tomato pests on colony growth and conidial germination of Paecilomyces fumosoroseus. Biol. Control 2004, 31, 398-404. [CrossRef]

73. Loureiro, E.; Moino, A.; Arnosti, A.; De Souza, G. Efeito de productos fitossanitarios químicos utilizados em alfase e crisantemo sobre fungus enomopatogenicos. Neotrop. Entomol. 2002, 31, 263-269. [CrossRef]

74. Gallego-Velásquez, J.; Cardona-Bustos, N.L.; Restrepo-Betancur, F. Compatibility of the entomopathogenic fungus Purpureocillium sp. cepa UdeA0106 with biocontrollers fungi and plant protection products, used on chrysanthemum crops. Act. Biol. 2014, 36, 173-187.

75. Avery, P.B.; Pick, D.A.; Aristizábal, L.F.; Kerrigan, J.; Powell, C.A.; Rogers, M.E.; Arthurs, S.P. Compatibility of Isaria fumosorosea (Hypocreales: Cordycipitaceae) blastospores with agricultural chemicals used for management of the Asian citrus psyllid, Diaphorina citri (Hemiptera: Liviidae). Insects 2013, 4, 694-711. [CrossRef] [PubMed]

76. Ondráèková, E.; Seidenglanz, M.; Šafáo, J. Effect of seventeen pesticides on mycelial growth of Akanthomyces, Beauveria, Cordyceps and Purpureocillium strains. Czech Mycol. 2019, 71, 123-135. [CrossRef]

77. Jacobs, H.; Gray, S.N.; Crump, D.H. Interactions between nematophagous fungi and consequences for their potential as biological agents for the control of potato cyst nematodes. Mycol. Res. 2003, 107, 47-56. [CrossRef] [PubMed]

78. Diánez, F.; Santos, M.; Carretero, F.; Marín, F. Trichoderma saturnisporum: A new biological control agent. J. Sci. Food Agric. 2016, 96, 1934-1944. [CrossRef] [PubMed]

79. Taufik, M.; Yusuf, D.N.; Boer, D.; Botek, M. Evaluating the ability of endophyte fungus to control VSD diseases in cocoa seeding. IOP Conf. Ser. Earth Environ. Sci. 2019, 382, 012011. [CrossRef]

80. Sornakili, A.; Thankappan, S.; Sridharan, A.P.; Nithya, P.; Uthandi, S. Antagonistic fungal endophytes and their metabolitemediated interactions against phytopathogens in rice. Physiol. Mol. Plant Pathol. 2020, 112, 101525. [CrossRef]

81. Marín-Chacón, M.A.; Rivera-Coto, G.; Villalobos-Moya, K.; Orozco-Rodríguez, R.; Orozco-Cayasso, S. Evaluación de hongos antagonistas de Botrytis cinerea Pers., en plantaciones de mora, Costa Rica. Agron. Costarric. 2017, 41, 7-18. [CrossRef] 